\title{
Matlab/Simulink Based Modeling to Study Effect of Partial Shadow on Solar Photovoltaic Array
}

\author{
Xuan Hieu Nguyen ${ }^{*}$
}

\begin{abstract}
Background: Solar module is considered as fundamental power transformation unit of Photovoltaic (PV) generation system. The performance of a PV array strongly depends on operating environmental conditions such as operating temperature, solar insolation, shading array configuration. Often PV arrays get shadowed fully or partially by passing cloud, building, poles, trees, etc. Under such partial shading conditions, the operation of PV arrays get more complicated with more than one peak and it is very important to predict the characteristics to obtain possible maximum power. Furthermore, the mismatch losses and hotspot effects caused by partially shading cannot only affect the output power of solar system also can bring security and reliability problem. However, it is quite expensive and takes much time to get operating output characteristics of PV arrays under non uniform working conditions. Therefore, it is necessary to have a simulation model to study the effect of partial shading on solar PV arrays' working characteristics. A $100 \mathrm{~W}$ solar panel is used as reference. The study also focuses on position of output peak power with varying location of shaded modules, different levels of solar irradiation as well as role of bypass diodes in this system.

Result: The I-V and P-V output curves of the solar PV arrays under partially shading conditions are given. The simulation results indicate that the higher number of shaded solar modules is, the lower value of power output is and the position of maximum power point does not depend on location of modules under shadow.

Conclusion: The paper provides an easy method to study the response of solar PV arrays under non uniform working conditions: partial shadow. In addition, the following points were also investigated:

- Impact of varying position of shaded modules on PV array's characteristics.

- Impact of different levels of solar irradiation accompany with varying temperature on solar PV array's operation under partially shading condition.

- Role of bypass diode in improving operation of solar system under non uniform condition.
\end{abstract}

Keywords: Matlab/Simulink, Photovoltaic arrays, Shading effect, P-V and I-V characteristics, Bypass diode

\section{Background}

The issue of modeling of PV modules/arrays under non uniform conditions such as shading condition has been largely investigated in literature and gets some certain results.

In initial studies, partial shading condition was just considered as one factor in the effect of environmental

*Correspondence: nxhieu@vnua.edu.vn; xuanhieu176@gmail.com Faculty of Engineering, Vietnam National University of Agriculture, Trau Quy town, Gia Lam district, Hanoi, Vietnam condition (solar insolation, temperature, etc.) on PV array's operation, for example in the research of Ibbini et al. (2014) so the result is quite limited and does not give reader overview on relationship between solar PV array and shadow effect.

A model developed from Tag tools in Simulink to study shading effect was proposed in the research of Mantri and Verma (2015) and Bouraiou et al. (2014). In this study, the role of bypass diode and varying levels of solar insolation on PV array's working characteristics was investigated. However, the gap of this

\section{Springer}

(c) 2015 Nguyen. This article is distributed under the terms of the Creative Commons Attribution 4.0 International License (http:// creativecommons.org/licenses/by/4.0/), which permits unrestricted use, distribution, and reproduction in any medium, provided you give appropriate credit to the original author(s) and the source, provide a link to the Creative Commons license, and indicate if changes were made. 
research is the limitation in the number of modules in an array (just two modules were considered) so the results are not adequate because in reality more than two modules combine together into solar arrays. Furthermore, another component called blocking diode which affects to operation of PV array was also not mentioned.

The gap of the researches mentioned above is filled in by Seyedmahmoudian et al. (2013), Belhaouas et al. (2013), Ramasamy et al. (2014) and Ramaprabha and Mathur (2012). From the work of Ramaprabha and Mathur (2012), an overview of different types of solar PV system configuration is given and from there a configuration is proposed to study effect of using more bypass diodes and varying $R_{s h}$. In this research, the study is just carried out with two levels of solar irradiation. Ramasamy et al. (2014) used the graphical user interface (GUI) tool to investigate effect of shadow on maximum power point tracker (MPPT) while Belhaouas et al. (2013) and Seyedmahmoudian et al. (2013) just considered impact of two and three bypass diodes.

Overall, above studies investigate impact of shaded modules on solar PV array's operation as well as role of bypass diode. However, the location of shaded modules which can affect to the PV system' characteristic shape is not emphasized. Furthermore in reality when solar irradiation reduces, the temperature drops accompany so different levels of solar irradiation under shading condition needs to be investigated with varying temperature but it is not provided in above studies.

As a result of that, this paper will focus on the gap mentioned above through following points:

- A proposed model is developed with Tag tools in Simulink environment. This model is based on the fundamental circuit equations of solar array considering effect of physical and environmental parameters so it indicates advantages in studying the role of these parameters on PV array's working characteristics.

- The relationship between varying location of shaded modules and PV system's characteristic shape is investigated.

- The impact of shading condition accompany with varying temperature on PV array's working characteristics is also investigated.

\section{Methods}

\section{Modeling of solar PV module in Matlab/Simulink} Solar cell, array equivalent circuit

The equivalent circuit of a PV cell is shown in Fig. 1. It consists of a current source $\mathrm{I}_{\mathrm{ph}}$ which represents the cell photo-current, shunt and series resistances of the cell $R_{s h}$

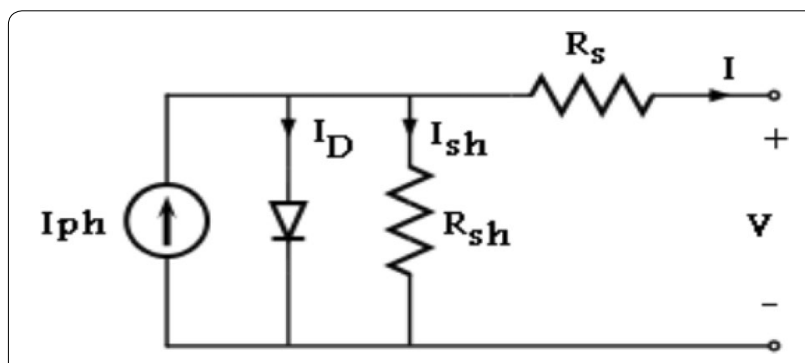

Fig. 1 A PV cell equivalent circuit (Salmi et al. 2012)

and $R_{s}$ respectively and a diode. Usually the value of $R_{s h}$ is very large and that of $R_{s}$ is very small, hence they may be neglected to simplify the analysis. Practically, PV cells are grouped in larger units called PV modules and these modules are connected in series or parallel to create PV arrays that are used to generate electricity in PV generation systems. The equivalent circuit for PV array is shown in Fig. 2.

The voltage and current characteristic equation of a solar cell is provided as: ( $\mathrm{Tu}$ and $\mathrm{Su}$ 2008; Salmi et al. 2012).

Module photo-current $\mathrm{I}_{\mathrm{ph}}$ :

$$
I_{p h}=\left[I_{s c}+K_{i}(T-298)\right] * I r / 1000
$$

In this equation, $I_{p h}$ is the photo-current, $I_{s c}$ is the short-circuit current, $K_{i}$ is the cell's short circuit current temperature coefficient, Ir is the sollar irradiation. Module reverse saturation current $\mathrm{I}_{\mathrm{rs}}$ :

$$
I_{r s}=I_{s c} /\left[\exp \left(q V_{O C} / N_{S} k n T\right)-1\right]
$$

where, $q$ is the electron charge, $\mathrm{V}_{\mathrm{OC}}$ is the open circuit voltage, $\mathrm{N}_{\mathrm{S}}$ is the number of solar cells connected in series, $k$ is the Boltzmann's constant, $n$ is the ideality factor of the diode, $T$ is the operating temperature. The module saturation current $\mathrm{I}_{0}$ varies with the cell temperature, which is given by:

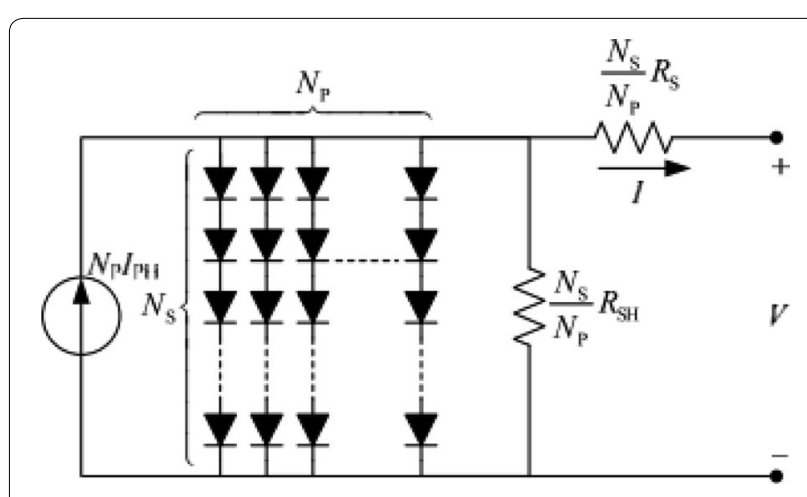

Fig. 2 Equivalent circuit of a solar array (Tu and Su 2008) 


$$
I_{0}=I_{r s}\left[\frac{T}{T_{r}}\right]^{3} \exp \left[\frac{q * E_{g 0}}{n k}\left(\frac{1}{T}-\frac{1}{T_{r}}\right)\right]
$$

Here, $q$ is the electron charge, $\mathrm{E}_{\mathrm{g} 0}$ is the band gap energy of the semiconductor, $R_{S}$ and $R_{s h}$ are the series and shunt resistors of the cell, respectively. The current output of PV module is:

$$
I=N_{P} * I_{p h}-N_{P} * I_{0} *\left[\exp \left(\frac{V / N_{S}+I * R_{s} / N_{P}}{n * V_{t}}\right)-1\right]-I_{s h}
$$

with

$$
V_{t}=\frac{k * T}{q}
$$

and

$$
I_{s h}=\frac{V * N_{P} / N_{S}+I * R_{S}}{R_{s h}}
$$

Here, $\mathrm{N}_{\mathrm{P}}$ is the number of solar PV modules connected in parallel, $\mathrm{V}_{\mathrm{t}}$ is the thermal voltage.

\section{Modeling of solar PV array in Matlab/Simulink}

Base on Eqs. from (1) to (6), a model of solar module is developed by using Tag tools in Simulink environment. The model includes six cells connected in series and it is given in Figs. 3 and 4.

As a result of that, six solar PV modules combine together to form a solar PV array. The proposed model is shown in Fig. 5.

\section{Reference model}

A $100 \mathrm{~W}$ solar PV module is taken as the reference module for simulation and the detailed parameters of module is given in Table 1 .

\section{Case study}

Effect of location and number of shaded modules

\begin{tabular}{ll}
\hline Case & Description \\
\hline 1 & $\begin{array}{c}\text { No shaded PV module (full irradiation on solar PV } \\
\text { array): } 1000 \mathrm{~W} / \mathrm{m}^{2}\end{array}$ \\
& One shaded PV module: the position of shaded \\
module changes from 1 to 6 respectively (shaded \\
module has: $\mathrm{Ir}=500 \mathrm{~W} / \mathrm{m}^{2}$, other modules in array \\
have $\mathrm{Ir}=1000 \mathrm{~W} / \mathrm{m}^{2}$ ) \\
Two shaded modules with same irradiation level : \\
$500 \mathrm{~W} / \mathrm{m}^{2}$ and others have $1000 \mathrm{~W} / \mathrm{m}^{2}$ \\
Module 1 and 2 are shaded \\
Module 1 and 3 are shaded \\
Module 2 and 3 are shaded
\end{tabular}

\begin{tabular}{ll}
\hline Case & Description \\
\hline 4 & Three shaded modules with same irradiation level \\
& $\left(500 \mathrm{~W} / \mathrm{m}^{2}\right)$, varying position of shaded modules \\
& Module 1,2 and 3 are shaded \\
& Module 1,2 and 4 are shaded \\
& Module 2,3 and 6 are shaded \\
& Three shade modules with different levels of irradia- \\
& tion: 500,300 and $100 \mathrm{~W} / \mathrm{m}^{2}$ \\
& Module 1,2 and 3 are shaded \\
& Module 1,2 and 4 are shaded \\
& Module 2,3 and 6 are shaded
\end{tabular}

\section{Effect of partial shadow and operating temperature}

In reality, when cells or modules are shaded partially or fully, the operating temperature of modules reduced so in this study real characteristic of power output according to effect of shadow and temperature together is also investigated. The study will be carried out in following cases:

\begin{tabular}{ll}
\hline Case & Description \\
\hline 6 & Modules 1, 2 and $3: 500 \mathrm{~W} / \mathrm{m}^{2}$ \\
& and operating temperature: \\
& $25^{\circ} \mathrm{C}$, others have $1000 \mathrm{~W} / \mathrm{m}^{2}$ \\
& $\left(\mathrm{~T}=25^{\circ} \mathrm{C}\right)$ \\
7 & Modules 1,2 and $3: 500 \mathrm{~W} / \mathrm{m}^{2}$ \\
& but operating temperature: \\
& $15^{\circ} \mathrm{C}$, others have $1000 \mathrm{~W} / \mathrm{m}^{2}$ \\
& $\left(\mathrm{~T}=25^{\circ} \mathrm{C}\right)$ \\
\hline
\end{tabular}

\section{Effect of bypass diode}

In order to study effect of bypass diode to operating function of solar PV system, a developed model was proposed in Fig. 5. The impact of bypass diode on power output of solar PV array will be discussed in two cases:

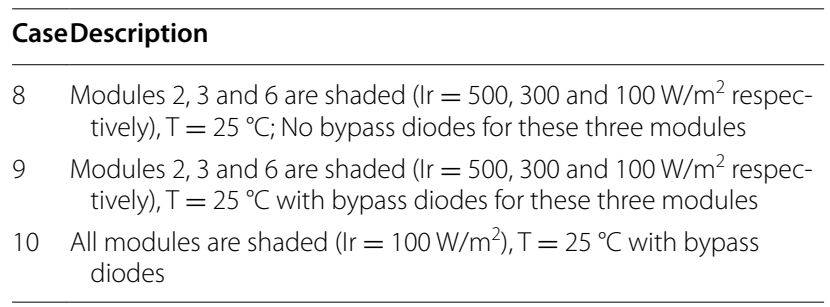

\section{Results and discussion}

Effect of location and number of shaded modules

The simulation results were shown in Figs. 6, 7, 8 and 9.

In case of 1 shaded module, the I-V curve were recorded with two steps while the $\mathrm{P}-\mathrm{V}$ curve has two peaks and the highest peak point is tended to $60-65 \%$ $\mathrm{V}_{\mathrm{OC}}$ and belong to first step in the curve.

As can be seen from Figs. 6, 7 and 8, two-steps I-V curves are seen in cases of 2 and 3 shaded modules but in these cases peak points are recorded in second peak of the curves. Furthermore, these peak points belong to $80-85 \% \mathrm{~V}_{\text {oc }}$. 

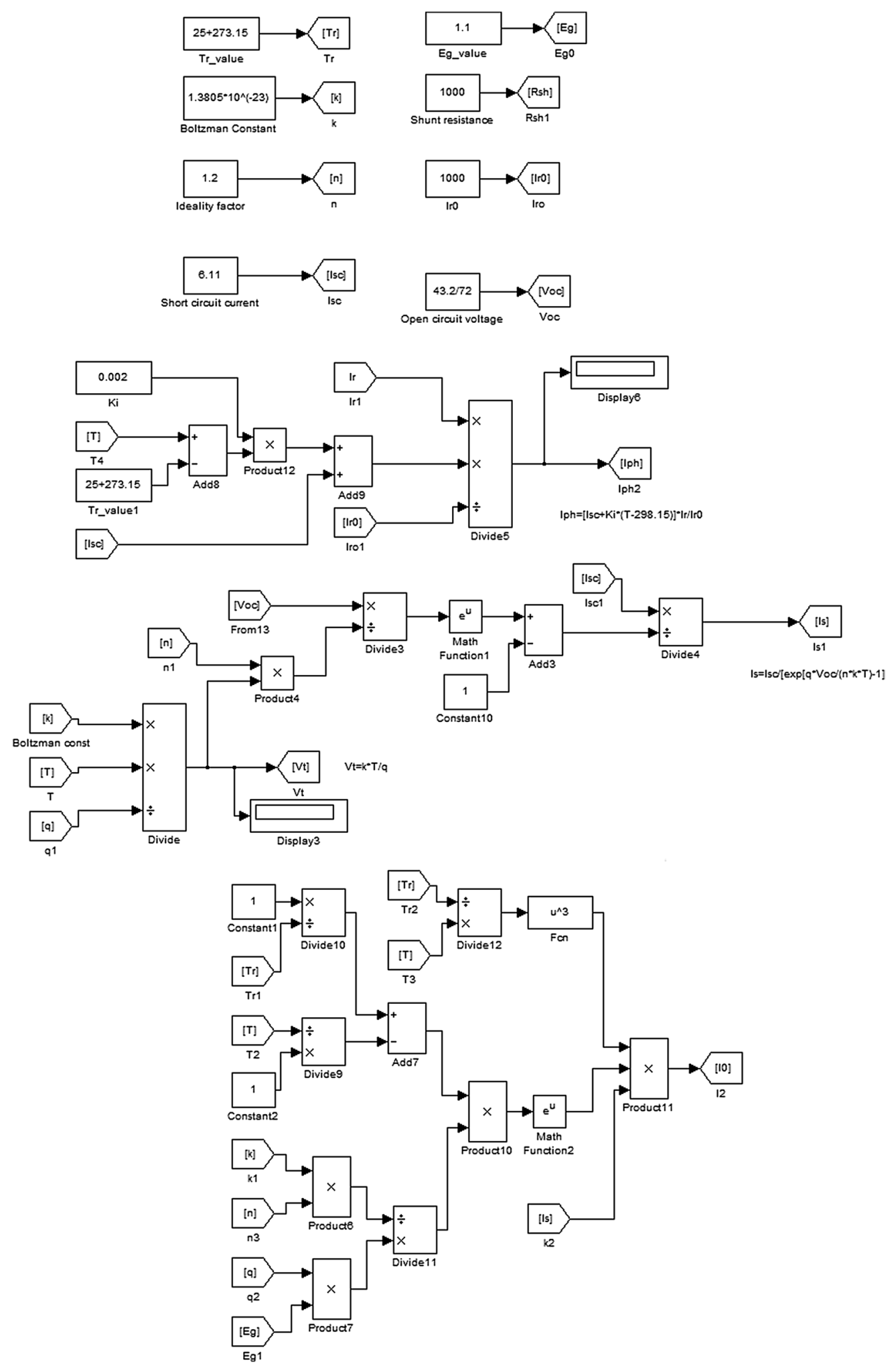

Fig. 3 Simulation model of a module consisting of 6 cells connected in series (modeling of Eqs. (1) to (3)) 
Table 1 Electrical characteristics data of DS-100 M PV module

\begin{tabular}{ll}
\hline Name & DS-100 M \\
\hline Rated power $\left(\mathrm{V}_{\mathrm{mp}}\right)$ & $100 \mathrm{~W}$ \\
Voltage at Maximum power $\left(\mathrm{V}_{\mathrm{mp}}\right)$ & $18 \mathrm{~V}$ \\
Current at Maximum power $\left(\mathrm{I}_{\mathrm{mp}}\right)$ & $5.55 \mathrm{~A}$ \\
Open circuit voltage $\left(\mathrm{V}_{\mathrm{OC}}\right)$ & $21.6 \mathrm{~V}$ \\
Short circuit current $\left(\mathrm{I}_{\mathrm{SC}}\right)$ & $6.11 \mathrm{~A}$ \\
Total number of cells in series $\left(\mathrm{N}_{\mathrm{S}}\right)$ & 36 \\
Total number of cells in parallel $\left(\mathrm{N}_{\mathrm{p}}\right)$ & 1 \\
Maximum system voltage & $1000 \mathrm{~V}$ \\
Range of operation temperature & $-40 \div 80^{\circ} \mathrm{C}$
\end{tabular}

The electrical specifications are under test conditions of irradiance of $1 \mathrm{~kW} / \mathrm{m}^{2}$, spectrum of 1.5 air masses and cell temperature of $25^{\circ} \mathrm{C}$

In case of 3 shaded modules, 4-step curves are seen in Fig. 9 (case 5) and the peak point is given in the second step of the diagram.

\section{Summary}

1. When solar PV system is shaded partially, the power output decreases.

2. The number of shaded modules increases, the number of peaks in power output increases.

3. With same number of shaded modules, similar curves are recorded with varying location of shaded modules. In other words, in case of same number of shaded modules similar output characteristic curves are given with varying position of these modules in the array.

4. Position of maximum power point is independent with varying number of shaded modules.

5. In cases of shaded modules with similar levels of solar insolation, PV curve peaks occur nearly around multiple of $80 \%$ of $\mathrm{V}_{\mathrm{oc}}$. Nevertheless, displacement between successive peaks comes nearly around $80 \%$ of array's $\mathrm{V}_{\mathrm{oc}}$.

6. However, in case study of shading modules under varying solar irradiation, PV curve peaks are tended to be around $50 \%$ of $\mathrm{V}_{\text {oc }}$.

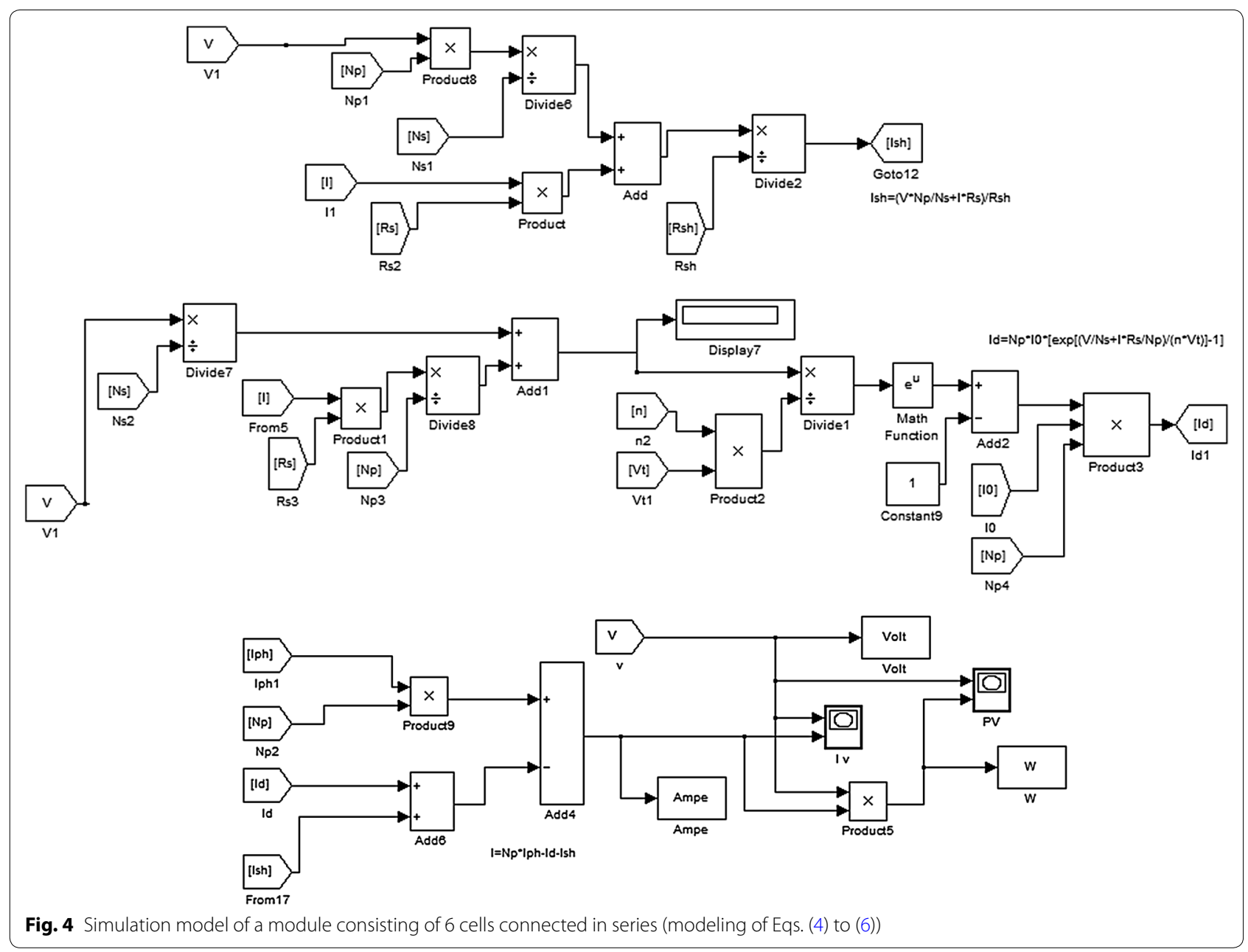




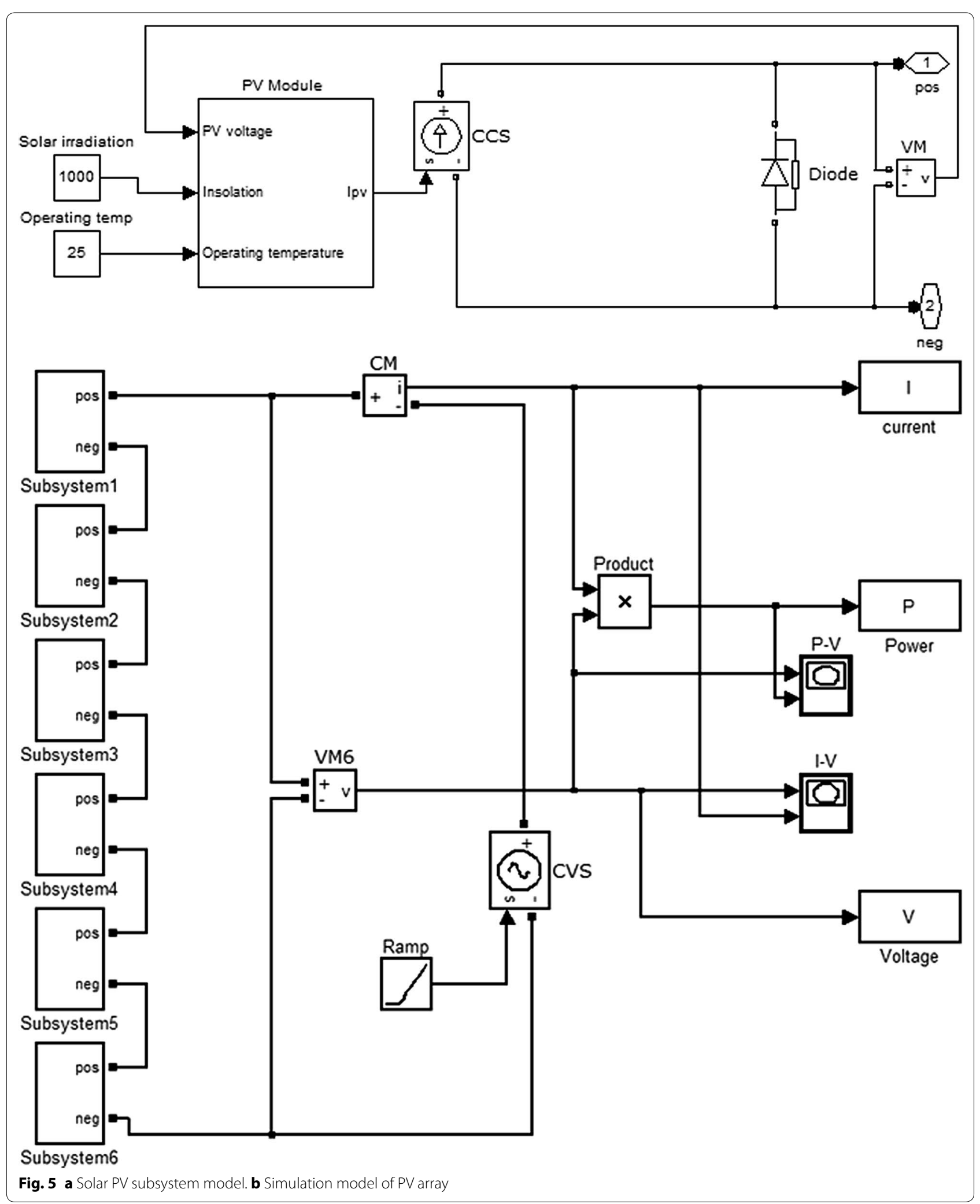




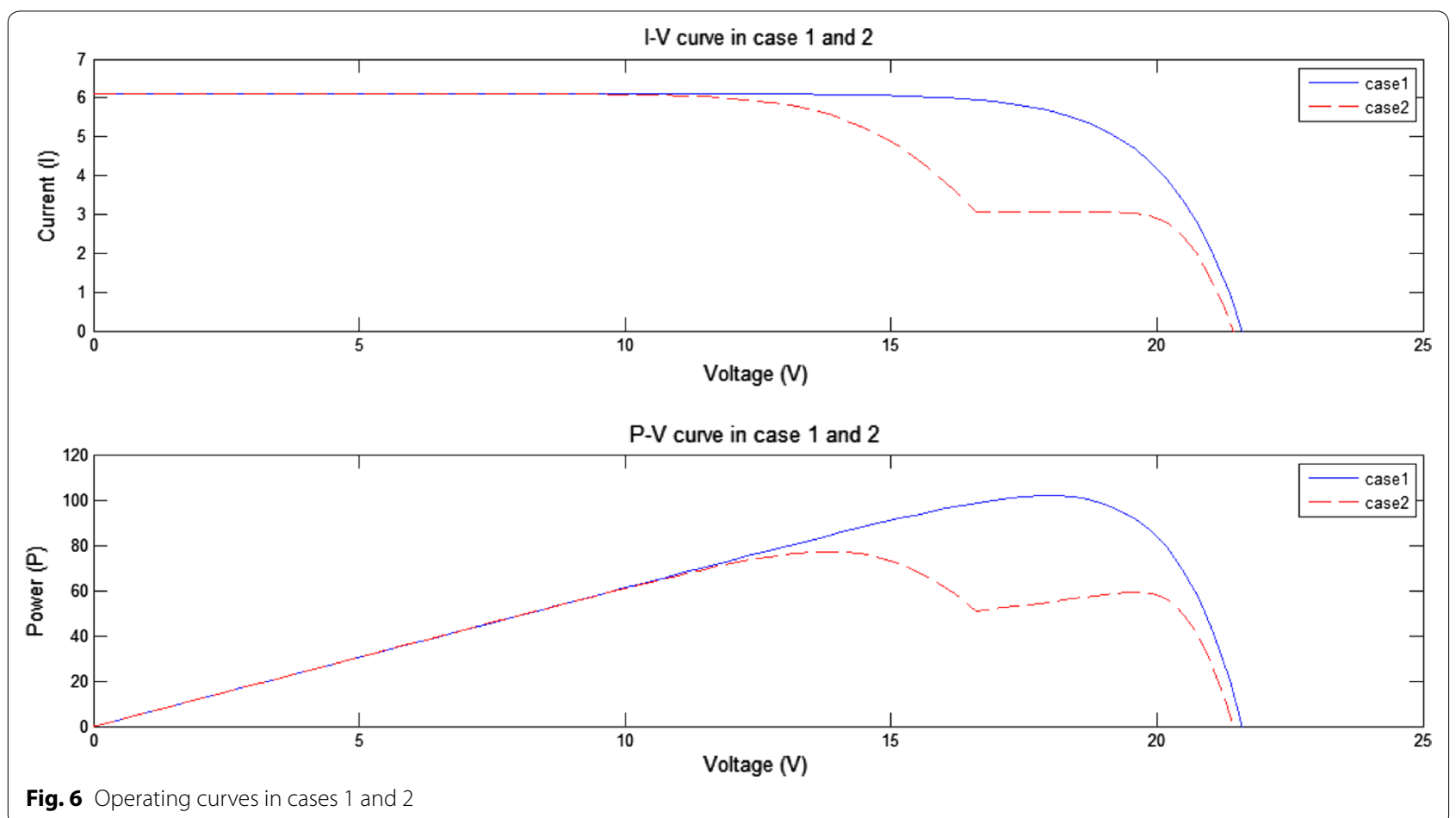

Fig. 6 Operating curves in cases 1 and 2

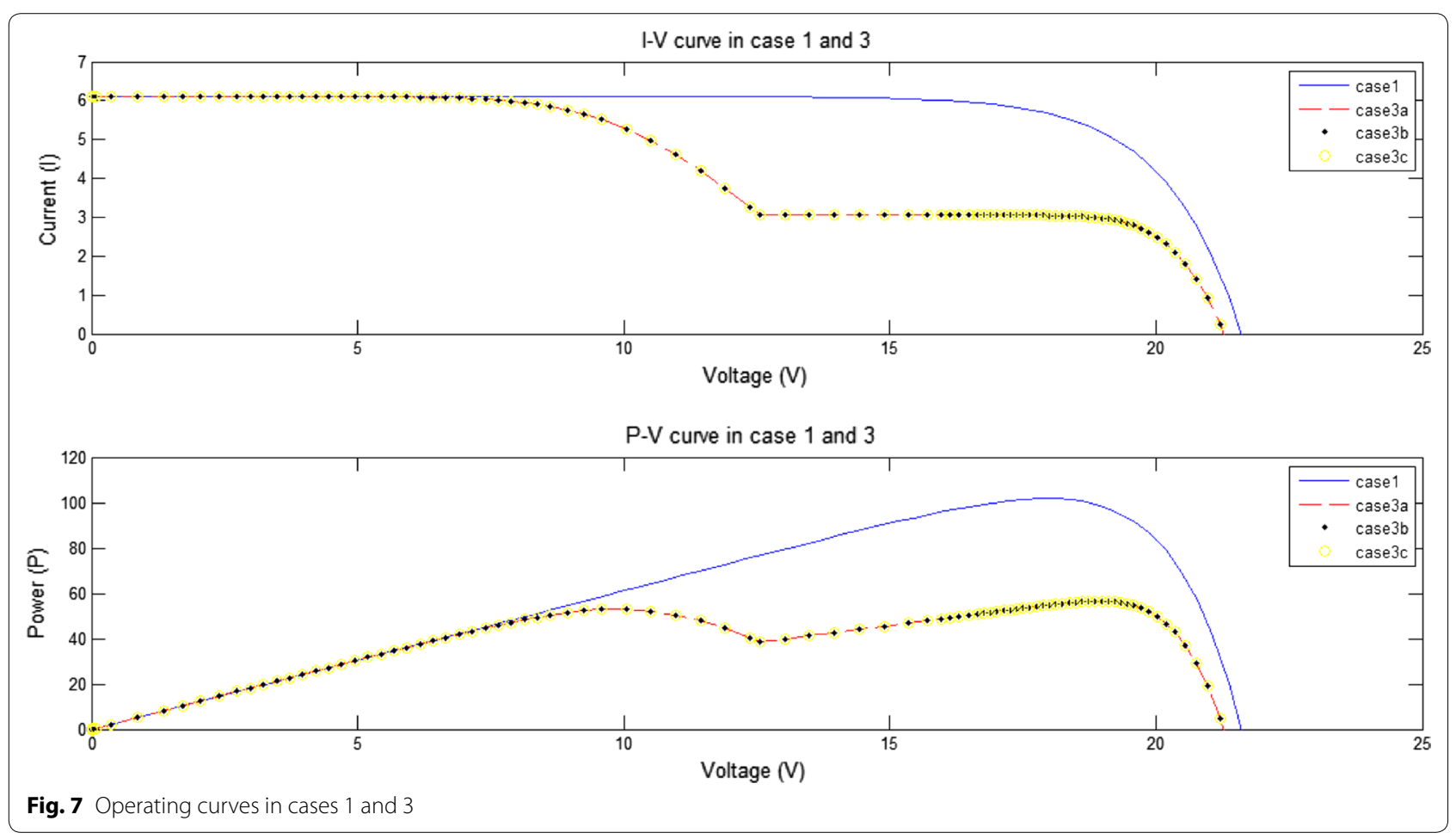



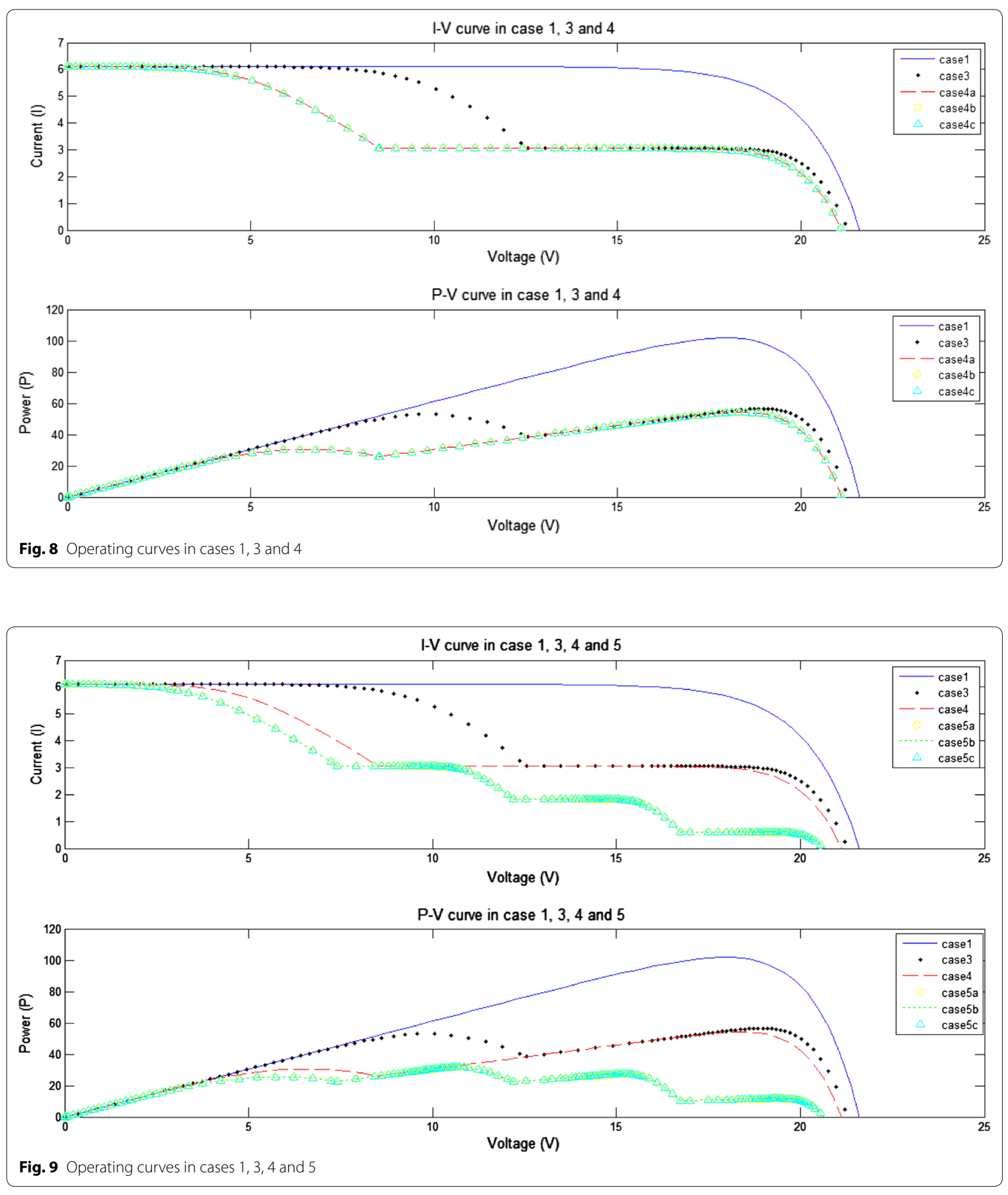


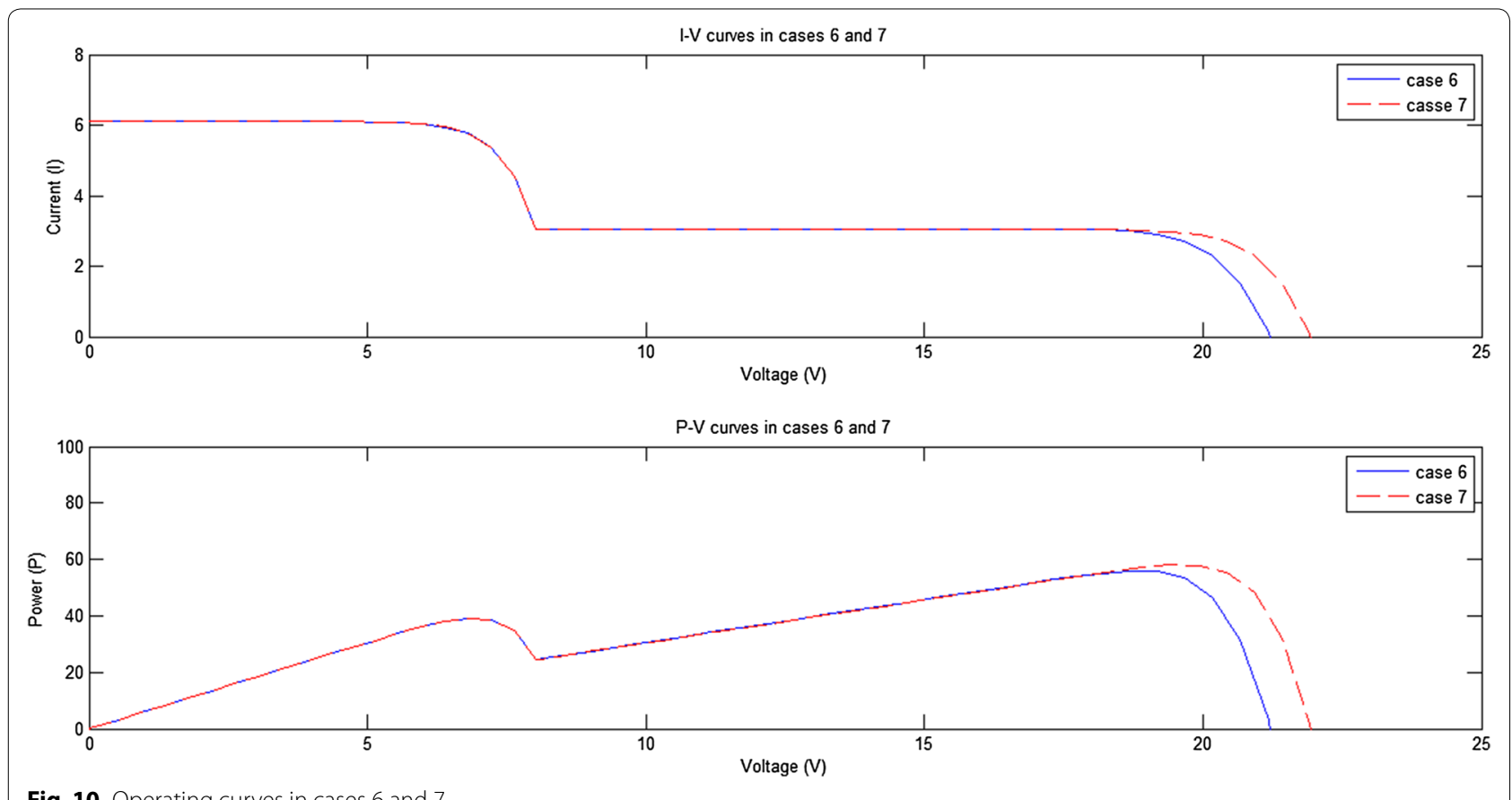

Fig. 10 Operating curves in cases 6 and 7

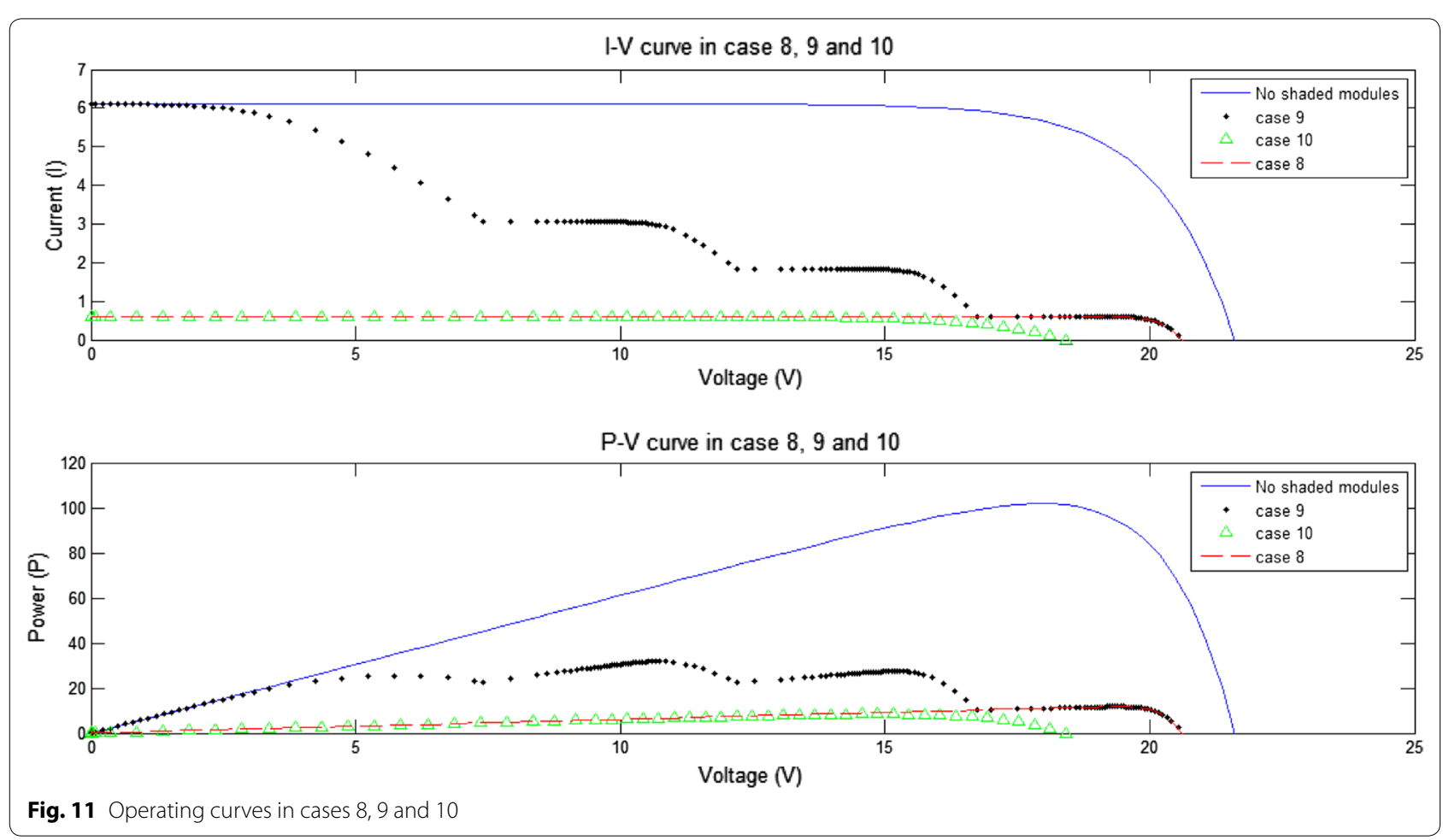


Effect of partial shadow and operating temperature

The simulation results are given in Fig. 10.

\section{Summary}

1. Similar I-V and P-V curves are recorded with and without considering varying temperature.

2. However, focusing on power output, higher power output is captured in case of lower operating temperature. Similarly, higher value of open voltage is also recorded when operating temperature reduces.

\section{Effect of bypass diode}

The results given in Fig. 11 show that:

1. A number of peaks may appear when the number of strings is connected in parallel with diodes. The number of peaks cannot be greater than the number of strings connected in parallel with bypass diode.

2. With bypass diodes, solar PV system gets higher power output comparing with the system without these diodes. This claims that bypass diodes improve operating function of solar PV system including series modules.

3. The shaded system under different levels of insolation without bypass diodes provides higher value in open circuit voltage and power output comparing to the system where all modules are shaded with irradiation of $100 \mathrm{~W} / \mathrm{m}^{2}$.

\section{Conclusions}

A Matlab/Simulink model for the solar PV cells, modules, and array is developed and presented in this paper. This model is based on the fundamental circuit equations of a solar PV array taking into the effects of physical and environmental parameters such as cell temperature, solar irradiation and shading condition. As a result of the study, the proposed model seems to be easy for other researchers to follow to build the model and study by themselves because it is based on the Eqs. from (1) to (6) and each equation has each model (shown in Fig. 3 and 4). Furthermore, such a model would provide effective tool to predict the behavior of solar array under changing climate and physical parameters due to all these parameters are included in the simulation model.

In addition, the proposed model is also used effectively to study the effect of shadow on operating characteristics of solar PV system and give clearance in some point as follows:

1. The higher number of shaded modules is, the lower value of power output is.
2. With a fixed number of shading modules, similar I-V and $\mathrm{P}-\mathrm{V}$ characteristic shape is recorded under varying position of modules shaded.

3. In cases of 1 or 2 shading modules, power peaks occur nearly about multiple of $80 \%$ of $\mathrm{V}_{\mathrm{oc}}$. However, in case of three modules under shading condition, peaks tend to be around $50 \%$ of $\mathrm{V}_{\mathrm{oc}}$.

4. Considering the appearance of operating temperature, solar PV array generates more energy under lower temperature.

5. Bypass diodes help to improve PV arrays' operating curve and enable them to provide more energy.

\section{Acknowledgements}

The authors are grateful to the support by this work through the project "Study, design and manufacture a solar PV system using SPV technology severed for chicken farms in Faculty of Animal Science, Vietnam National University of Agriculture", Vietnam (2014-2017).

Compliance with ethical guidelines

Competing interests

The author declares that they have no competing interests.

Received: 7 August 2015 Accepted: 17 September 2015

Published online: 02 November 2015

\section{References}

Belhaouas N et al (2013) Matlab-Simulink of photovoltaic system based on a two-diode model simulator with shaded solar cells. Revue des Energies Renouvelables 16(1):9

Bouraiou A et al (2014) Matlab/Simulink based modeling and simulation of photovoltaic array under partial shading. In: International conference on green energy and environmental engineering (GEEE-2014): 5

Ibbini MS et al (2014) Simscape solar cells model analysis and design. Computer applications in environmental sciences and renewable energy. World Scientific and Engineering Academy and Society (WSEAS): 7

Mantri A, Verma DA (2015) Developed simulated circuit of photovoltaic array under partially shading conditions. Int J Res (IJR) 2(3):6

Ramaprabha R, Mathur BL (2012) A comprehensive review and analysis of solar photovoltaic array configurations under partial shaded conditions. Int J Photoenergy 2012:16. doi:10.1155/2012/120214

Ramasamy S et al (2014) An intelligent differential evolution based maximum power point tracking (MPPT) technique for partially shaded photo voltaic (PV) array. Int J Adv Soft Comput Appl 6(2):16

Salmi T, Bouzguenda M, Gastli A, Masmoudi A (2012) Matlab/Simulink based modelling of solar photovoltaic cell. Int J Renew Energy Res 2(2):6

Seyedmahmoudian M et al (2013) Analytical modeling of partially shaded photovoltaic systems. Energies 6:17

Tu H-LT, Su Y-J (2008) Development of generalized photovoltaic model using Matlab/Simulink. Proc World Congr Eng Comput Sci 2008:6 